\title{
Fear and Anger in the Time of Covid-19
}

\author{
Carmelo Guarino \\ $\mathrm{PhD}$ in Sociology \\ Consultant for the Education and Health Promotion Activities of the Municipality of Palermo \\ Azienda Ospedaliera \\ Ospedali Riuniti \\ "Villa Sofia-Cervello" \\ Viale Strasburgo n. 133 \\ 90146 - Palermo - Italy
}

\begin{abstract}
While Covid-19 is still shrouded in an aura of unknowability, unpredictability and epidemiological uncertainty, it is all the more true that the implications and consequences of the pandemic and the restrictive measures on the scale of basic emotions are equally unknown and incomprehensible. This systematic review aims precisely to explore this phenomenon in order to identify the possible consequences on the dynamics that bind people.
\end{abstract}

Keywords: Covid-19 - Emotion - Fear - Anger

\section{Introduction}

The Covid-19 pandemic seems to have given a sudden acceleration to that social change already theorized by Zygmunt Bauman in Liquid Modernity of 2000 based on the idea of perpetual change in which the only certainty is uncertainty. A change that moves in the direction of what Ulrich Beck in Metamorphosis of the world of 2016 has defined metamorphosis: an all-encompassing, unintentional, nor ideological change that imposes itself inexorably on everyday life, with a tremendous acceleration that burns over time the existing possibilities of thinking and acting. And whose outcome seems indefinable, like an unknown, unknown territory. As Alain Touraine wrote in Unnouveauparadigme. Pour comprendrele monde d'aujourd'hui of 2005 , we live in a contemporaneity marked by the end of society, the rupture of social ties, loneliness, the crisis of identities, free from obligations of belonging and imposed rules. On the other hand, if Bauman's liquidity and the end of Touraine society tell of the bewilderment, unease and disintegration of consciences induced by the drift of modernity, perceived as a perpetual crisis, according to the sociologist Carlo Bordoni, part of this change was caused by the pandemic by Covid-19 which only accelerated its dynamics (Bordoni, 2020).

The main indicator of this change, to which the Sars-Cov-2 has impressed so much acceleration, is the rediscovered centrality of the State (as the producer of the rules and regulations necessary for social control and the prevention of risky behaviour in the name of the protection of public health), science (as the source of reliable, valid and verifiable knowledge and truths) and the Community (compared to a multitude of individuals animated by anger and aggression, greedy and prone to indiscriminate exploitation of possibilities). Along the lines of Max Weber, we could say that the pandemic from Covid-19 acting as a powerful and extraordinary accelerator element, has contributed to the ongoing change in the direction of "a nascent state", of a new time, of an emerging condition that, however, as any change simultaneously produces disorientation and restlessness, fear and anger.

The appearance on the world scene of the pandemic has therefore determined effects, consequences and implication on the sphere of human relations and on the functioning of social systems, which have destabilized the balance, putting at risk its maintenance. The entire dramaturgical structure already described by Ervin Goffman in The presentation of self in everyday life of 1959 seems to have been deeply disturbed and subverted. It seems legitimate to maintain that the Covid-19 pandemic acted as a slatentizing factor, rather than a causal factor, of emotional phenomena such as anger, fear, anguish.

This confirms what Bauman argued in Retrotopia in 2017 that an ancient and deep process of social retreat in the tribal sense is underway, where stigma and aversion to the "unequal" and to the foreigner operate in the direction of a progressive social disintegration. The effects of this process seem to have momentarily shifted from the more properly political plane of globalization processes to the more specifically relational and social one.

The fear of immigrants has become the fear of contagion, anger against foreigners translates into anger against offenders of restrictions and containment measures; social condemnation of the different is transformed into stigma and relative marginalization of the plague-spreader. This according to psycho-social dynamics that identify the high 
morbidity and mortality of the pandemic a powerful detonator of our uncertainties and vulnerabilities, widespread and indistinct, that Bauman in Liquid fear of 2006 has synthesized in the concept of "fear".

\section{The research: a systematic review}

This work investigates the fear and anger triggered by psycho-social discomfort induced by Covid-19 pandemic and its social and economic consequences, through a systematic review of the most current scientific evidence on the subject.

\subsection{Method}

The systematic review was carried out in January-August 2020. The inclusion criteria adopted are attributable to the principle of the sociological relevance of the problem under investigation and to the relevance of scientific evidence (Ruggeri, 2010, pp. 109-121; Giarelli, Venneri, 2009, pp. 148-152; Sala et al., 2006). The research, using the terms "fear", "angry", "Covid-19" (combined through the boolean operators OR and AND), has been carried out in the following databases:

- $\quad$ EBSCOhost Research Databases and, specifically, SocINDEX with Full Text e Psychology and Behavioral Sciences Collection;

- $\quad$ Pubmed.gov della US National Library of Medicine del National Institut of Health;

- $\quad$ Cochrane Database of Systematic Reviews of Cochrane Library.

The inclusion criteria adopted were:

- $\quad$ research focus: fear and anger at the time of Covid19;

- $\quad$ reference years of publications: 2020 (to assess scientific evidence specifically related to Covid-19);

- $\quad$ independent scientific literature at international level;

- $\quad$ work in English.

\subsection{Results}

This has allowed the selection of 125 international studies that have been subjected to preliminary analysis of abstracts which led to a total of 57 studies analyzed in full text. This subsequent phase of analysis led to a further selection of studies, resulting in a total of 20 studies (Table 2) ${ }^{1}$. The research fosus has been further defined and refined through the use of the P\&PICO method and the complementary Facet analysis (Table 1) ${ }^{2}$.

Table 1 - Specification of the initial question and definition of the research scope: from the P\&PICO method to the Facet analysis system

\begin{tabular}{clll}
\hline Population & \multicolumn{1}{c}{ Problem } & \multicolumn{1}{c}{$\begin{array}{c}\text { Comparison and } \\
\text { approch }\end{array}$} & \multicolumn{1}{c}{ Outcome } \\
\hline General population & $\begin{array}{l}\text { Covid-19, contagion, } \\
\text { anger, fear, } \\
\text { stigmatization, } \\
\text { prejudice }\end{array}$ & $\begin{array}{l}\text { Analysis and } \\
\text { discussion of the main } \\
\text { results of the evidence } \\
\text { considered, with the } \\
\text { approach of Grounded } \\
\text { theory }\end{array}$ & $\begin{array}{l}\text { Coping strategies, adequate } \\
\text { of emotions, compliance } \\
\text { with behavioural norms of } \\
\text { prevention, State } \\
\text { intervention }\end{array}$ \\
& & &
\end{tabular}

\footnotetext{
${ }^{1}$ Unexpectedly or perhaps predictably, exploratory research revealed a research focus relation to the phenomena of domestic violence and suicide. Therefore, the studies identified have become part of the analysis of the present review in order to enucleate further dimensions of understanding and interpretation of the phenomenon under investigation.

${ }^{2}$ For the definition of the initial question, reference was made to the P\&PICO methodology (Problem \& patient, intervention, control outcome 9 which allows to summarize the process of specification of the clinical question. The PICO method, which in this case has been adapted to the specific theme, requires the preliminary specification of two questions. The first, clinical: what interests me (negative emotions, anger, fear, consequences in terms of personal and public well-being, etc.)? The second, methodological: whit respect to the initial question, what is the most appropriate study design? (Sala et al., 2006). Instead, the system of Facet Analysis, once identified and systematized the essential concepts of the research question, has allowed to widen and deepen further the scope of analysis (Hjorland, 2013).
} 


\begin{tabular}{ll} 
Vulnerability & Sars-Cov-2 \\
Emotions & Pandemic \\
Anger & Vaccine \\
Fear & Risk of contagion \\
Sadness & Perception of risk \\
Disgust & Personal protective \\
Happiness & equipment \\
Reactions to distress & Social distancing \\
from Covid19 & Isolation \\
Social relations & Quarantine \\
Individual well-being & Solitude \\
Collective well-being & Economic crisis \\
Public health & Job loss \\
Domestic violence & Impoverishment \\
\multirow{\Xi}{\Xi}{ Women } & Addictions \\
Children & Alcohol abuse \\
\multirow{\Xi}{\Xi}{ Suicidal behaviour } & \\
&
\end{tabular}

Growing awareness of
contagion risks
Safe behaviors
Test
Coping strategies
Educational policies
Multidisciplinary support
teams
Information
Media
Institutions
Social media
Police forces
Social services
Health care

Growing awareness of

Safe behaviors

Test

Coping strategies

Educational policies

Multidisciplinary support

teams

Information

Media

Institutions

Social media

Social services

Health care

In this way, the review of the studies, consistent with the Cochrane method, and in line with the principles of the Grounded theory (Corbin and Strauss, 1990; Glaser and Strauss, 2012), has allowed to:

- $\quad$ immediately restore the phenomenological complexity of the research focus;

- $\quad$ lay the foundations for a theoretical sensitivity analytical structure;

- $\quad$ maximize the logic of discovery.

Table 2 - Synopsis of the studies analysed

\begin{tabular}{|c|c|c|c|c|c|}
\hline Authors & Objectives & $\begin{array}{l}\text { Type of } \\
\text { study }\end{array}$ & Participants & $\begin{array}{l}\text { Dimensions } \\
\text { investigated }\end{array}$ & Conclusions \\
\hline $\begin{array}{l}\text { Torales et } \\
\text { al., } 2020\end{array}$ & $\begin{array}{l}\text { Analysis of the } \\
\text { effects of the } \\
\text { Covid } 19 \\
\text { pandemic on } \\
\text { people's } \\
\text { relational well- } \\
\text { being }\end{array}$ & $\begin{array}{l}\text { Systematic } \\
\text { review }\end{array}$ & $\begin{array}{c}24 \\
\text { scientific } \\
\text { studies }\end{array}$ & $\begin{array}{l}\text { Effects of the } \\
\text { pandemic on } \\
\text { people's } \\
\text { psychological and } \\
\text { social well-being }\end{array}$ & $\begin{array}{l}\text { The study suggests that the } \\
\text { attention of government } \\
\text { authorities around the world, } \\
\text { focusing on the most closely } \\
\text { epidemiological and clinical } \\
\text { data, is neglecting the effects } \\
\text { of the disease on psycho-well- } \\
\text { beingsocial of people with the } \\
\text { risk that the pandemic may } \\
\text { evolve into emerging problems } \\
\text { of health isolation, conflict and } \\
\text { long-term stigma }\end{array}$ \\
\hline $\begin{array}{l}\text { Trnka, } \\
\text { Lorenco, } \\
2020\end{array}$ & $\begin{array}{l}\text { Analysis of the } \\
\text { psycho-social } \\
\text { reactions of the } \\
\text { pandemic from } \\
\text { Covid-19 }\end{array}$ & Survey & $\begin{array}{c}1000 \\
\text { participants }\end{array}$ & $\begin{array}{l}\text { Relationship } \\
\text { between pandemic, } \\
\text { anger and fea }\end{array}$ & $\begin{array}{l}\text { The study shows a significant } \\
\text { positive correlation between } \\
\text { the consequences of the } \\
\text { pandemic and emotional } \\
\text { reactions related to anger and } \\
\text { fear }\end{array}$ \\
\hline $\begin{array}{l}\text { Lwinet al., } \\
2020\end{array}$ & $\begin{array}{l}\text { Exploring } \\
\text { trends of fear, } \\
\text { anger, sadness } \\
\text { and joy in } \\
\text { social media } \\
\text { narratives } \\
\text { during the } \\
\text { Covid-19 } \\
\text { pandemic }\end{array}$ & $\begin{array}{l}\text { Analysis of } \\
\text { tweets } \\
\text { through } \\
\text { Plutchik's } \\
\text { Wheel of } \\
\text { Emotions }\end{array}$ & $\begin{array}{l}\text { Over } 20 \\
\text { million } \\
\text { tweets }\end{array}$ & $\begin{array}{l}\text { Relationship } \\
\text { between protective } \\
\text { measures and } \\
\text { emotions such as } \\
\text { anger and fear }\end{array}$ & $\begin{array}{l}\text { According to the study, the } \\
\text { most widespread public } \\
\text { emotions during the pandemic } \\
\text { were fear and anger. Fear } \\
\text { seems to be linked to the } \\
\text { unavailability of protective } \\
\text { equipment, tests and targeted } \\
\text { therapies while anger has } \\
\text { shifted from the field of } \\
\text { xenophobia to that of isolation } \\
\text { provisions }\end{array}$ \\
\hline $\begin{array}{l}\text { Cerbaraet } \\
\text { al., } 2020\end{array}$ & $\begin{array}{l}\text { Analysis of the } \\
\text { correlation } \\
\text { between social } \\
\text { distancing and }\end{array}$ & $\begin{array}{l}\text { Web- } \\
\text { survey }\end{array}$ & $\begin{array}{c}140.656 \\
\text { participants }\end{array}$ & $\begin{array}{l}\text { Relationship } \\
\text { between negative } \\
\text { emotions and } \\
\text { primary needs }\end{array}$ & $\begin{array}{l}\text { The study shows the existence } \\
\text { of links between negative } \\
\text { emotions and primary needs as } \\
\text { a result of the Covid-19 }\end{array}$ \\
\hline
\end{tabular}




\begin{tabular}{|c|c|c|c|c|c|}
\hline & $\begin{array}{l}\text { isolation and } \\
\text { negative } \\
\text { emotions }\end{array}$ & & & & pandemic worldwide \\
\hline $\begin{array}{l}\text { Del } \\
\text { Carmen } \\
\text { Pérez- } \\
\text { Fuenteset } \\
\text { al., } 2020\end{array}$ & $\begin{array}{l}\text { Analysis of the } \\
\text { effects of } \\
\text { exceptionally } \\
\text { stressful } \\
\text { situations, such } \\
\text { as the current } \\
\text { health risk, on } \\
\text { the cognitive } \\
\text { and emotional } \\
\text { state of the } \\
\text { individual }\end{array}$ & $\begin{array}{l}\text { Cross- } \\
\text { sectional } \\
\text { study }\end{array}$ & $\begin{array}{c}1014 \\
\text { participants }\end{array}$ & $\begin{array}{l}\text { Relationships } \\
\text { between perceived } \\
\text { threat and negative } \\
\text { emotions }\end{array}$ & $\begin{array}{l}\text { The study shows a circular } \\
\text { relationship between perceived } \\
\text { threat and negative mood and, } \\
\text { in turn, between negative } \\
\text { mood increased feeling of } \\
\text { threat }\end{array}$ \\
\hline $\begin{array}{l}\text { Taleviet } \\
\text { al., } 2020\end{array}$ & $\begin{array}{l}\text { Analysis of the } \\
\text { effects of the } \\
\text { pandemic from } \\
\text { Covid-19 on } \\
\text { people's mental } \\
\text { well-being }\end{array}$ & $\begin{array}{c}\text { Systematic } \\
\text { review }\end{array}$ & $\begin{array}{c}15 \\
\text { scientific } \\
\text { studies }\end{array}$ & $\begin{array}{l}\text { Relationship } \\
\text { between risk } \\
\text { perception and } \\
\text { maladaptive } \\
\text { behavior, emotional } \\
\text { distress and } \\
\text { defensive responses }\end{array}$ & $\begin{array}{l}\text { The results confirm the } \\
\text { existence of a relationship } \\
\text { between anger and fear and the } \\
\text { perception of a state of } \\
\text { vulnerability }\end{array}$ \\
\hline $\begin{array}{l}\text { Vinkerset } \\
\text { al., } 2020\end{array}$ & $\begin{array}{l}\text { Analysis of the } \\
\text { psycho-social } \\
\text { disorientation } \\
\text { induced by the } \\
\text { pandemic and } \\
\text { the role of } \\
\text { resilience }\end{array}$ & $\begin{array}{l}\text { Narrative } \\
\text { reviews }\end{array}$ & $\begin{array}{c}13 \\
\text { scientific } \\
\text { studies }\end{array}$ & $\begin{array}{l}\text { Relation between } \\
\text { Covid-19 and social } \\
\text { resilience }\end{array}$ & $\begin{array}{l}\text { According to the study, the } \\
\text { pandemic, which has } \\
\text { generated individual and } \\
\text { collective disturbance in the } \\
\text { social system, requires a } \\
\text { collective effort to restore } \\
\text { social control dynamics in the } \\
\text { direction of a new general } \\
\text { socialization }\end{array}$ \\
\hline $\begin{array}{l}\text { Brooks et } \\
a l ., 2020\end{array}$ & $\begin{array}{l}\text { Analysis of } \\
\text { anger and post- } \\
\text { traumatic stress } \\
\text { symptoms }\end{array}$ & $\begin{array}{c}\text { Systematic } \\
\text { review }\end{array}$ & $\begin{array}{c}24 \\
\text { scientific } \\
\text { studies }\end{array}$ & $\begin{array}{l}\text { Relationship } \\
\text { between restrictive } \\
\text { measures and anger }\end{array}$ & $\begin{array}{l}\text { Most negative emotions seem } \\
\text { to be correlated with } \\
\text { restrictions of freedoms to } \\
\text { control contagion }\end{array}$ \\
\hline $\begin{array}{l}\text { Shanahan } \\
\text { et al., } \\
2020\end{array}$ & $\begin{array}{l}\text { Analysis of the } \\
\text { emotional } \\
\text { discomfort } \\
\text { caused by } \\
\text { Covid-19 }\end{array}$ & $\begin{array}{l}\text { Cohort } \\
\text { study }\end{array}$ & $\begin{array}{c}768 \\
\text { participants }\end{array}$ & $\begin{array}{l}\text { Relationship } \\
\text { between anger, } \\
\text { perceived stress and } \\
\text { pandemic }\end{array}$ & $\begin{array}{l}\text { Pre-Covid-19 emotional } \\
\text { discomfort emerges as the } \\
\text { strongest predictor of } \\
\text { emotional discomfort during } \\
\text { the pandemic, followed by } \\
\text { economic and psychosocial } \\
\text { pandemic stress (e.g. lifestyle } \\
\text { and economic disturbances) } \\
\text { and pre-pandemic social } \\
\text { despair and stress }\end{array}$ \\
\hline $\begin{array}{l}\text { Bezerraet } \\
\text { al., } 2020\end{array}$ & $\begin{array}{l}\text { Analysis of the } \\
\text { consequences } \\
\text { of the } \\
\text { pandemic from } \\
\text { Covid-19 on } \\
\text { the social well- } \\
\text { being of people }\end{array}$ & $\begin{array}{l}\text { Web- } \\
\text { survey }\end{array}$ & $\begin{array}{c}16.440 \\
\text { participants }\end{array}$ & $\begin{array}{l}\text { Relationship } \\
\text { between restrictive } \\
\text { measures and anger }\end{array}$ & $\begin{array}{l}\text { According to the study there is } \\
\text { a positive correlation between } \\
\text { restrictive measures and social } \\
\text { isolation and anxiety and } \\
\text { anger, frustration and family } \\
\text { conflicts }\end{array}$ \\
\hline $\begin{array}{l}\text { Roeschet } \\
\text { al., } 2020\end{array}$ & $\begin{array}{l}\text { Analysis of } \\
\text { domestic } \\
\text { violence } \\
\text { following the } \\
\text { pandemic from } \\
\text { Covid-19 }\end{array}$ & $\begin{array}{c}\text { Systematic } \\
\text { review }\end{array}$ & $\begin{array}{c}14 \\
\text { scientific } \\
\text { studies and } \\
\text { report }\end{array}$ & $\begin{array}{l}\text { Relationship } \\
\text { between domestic } \\
\text { violence and } \\
\text { psycho-social stress }\end{array}$ & $\begin{array}{l}\text { The psycho-physical stress, } \\
\text { fear and anger induced by } \\
\text { economic and social crises } \\
\text { following events such as } \\
\text { epidemics, conflicts and } \\
\text { humanitarian disasters leads to } \\
\text { an exponential increase in } \\
\text { family violence in the world }\end{array}$ \\
\hline Marques & Analysis of & Systematic & 40 & Relationship & The psycho-physical stress, \\
\hline
\end{tabular}




\begin{tabular}{|c|c|c|c|c|c|}
\hline $\begin{array}{ll}e t & a l ., \\
2020 & \end{array}$ & $\begin{array}{l}\text { domestic } \\
\text { violence } \\
\text { following the } \\
\text { pandemic from } \\
\text { Covid-19 }\end{array}$ & review & $\begin{array}{l}\text { scientific } \\
\text { studies }\end{array}$ & $\begin{array}{l}\text { between domestic } \\
\text { violence and fear } \\
\text { and aggression }\end{array}$ & $\begin{array}{l}\text { fear and anger induced by the } \\
\text { pandemic and its } \\
\text { consequences leads to an } \\
\text { increase in aggression and } \\
\text { abuse against women and } \\
\text { children }\end{array}$ \\
\hline $\begin{array}{l}\text { Voraet al., } \\
2020\end{array}$ & $\begin{array}{l}\text { Study of the } \\
\text { consequences } \\
\text { of the } \\
\text { pandemic from } \\
\text { Covid-19 on } \\
\text { the } \\
\text { phenomenon of } \\
\text { domestic } \\
\text { violence }\end{array}$ & $\begin{array}{c}\text { Systematic } \\
\text { review }\end{array}$ & $\begin{array}{c}10 \\
\text { scientific } \\
\text { studies and } \\
\text { report }\end{array}$ & $\begin{array}{l}\text { Relationship } \\
\text { between domestic } \\
\text { violence and fear } \\
\text { and aggression }\end{array}$ & $\begin{array}{l}\text { Psycho-physical stress, } \\
\text { pandemic-induced fear and } \\
\text { anger, along with alcohol } \\
\text { abuse and addiction, increases } \\
\text { the incidence of domestic } \\
\text { violence }\end{array}$ \\
\hline $\begin{array}{l}\text { Moreira, } \\
\text { da Costa, } \\
2020\end{array}$ & $\begin{array}{l}\text { Analysis of } \\
\text { domestic } \\
\text { violence during } \\
\text { crises }\end{array}$ & $\begin{array}{l}\text { Narrative } \\
\text { review }\end{array}$ & $\begin{array}{c}35 \\
\text { scientific } \\
\text { studies }\end{array}$ & $\begin{array}{l}\text { Relationship } \\
\text { between domestic } \\
\text { violence and } \\
\text { pandemic }\end{array}$ & $\begin{array}{l}\text { According to the conflict } \\
\text { dynamics within families and } \\
\text { aggressive attitudes pre- } \\
\text { existing to the pandemic are } \\
\text { significant predictive factors } \\
\text { of an escalation of domestic } \\
\text { violence exacerbated by fear } \\
\text { of disease, loss of job and risk } \\
\text { of impoverishment }\end{array}$ \\
\hline $\begin{array}{l}\text { Mohase, } \\
2020\end{array}$ & $\begin{array}{l}\text { Complaint of } \\
\text { the } \\
\text { perspectives of } \\
\text { increase of the } \\
\text { phenomenon }\end{array}$ & Editorial & & $\begin{array}{l}\text { Relationship } \\
\text { between restrictive } \\
\text { measures and the } \\
\text { incidence of } \\
\text { domestic violence in } \\
\text { the world }\end{array}$ & $\begin{array}{l}\text { According to the WHO and } \\
\text { the United Nations, the } \\
\text { increase in cases of domestic } \\
\text { violence is reaching levels that } \\
\text { force governments to take } \\
\text { targeted measures to tackle the } \\
\text { phenomenon }\end{array}$ \\
\hline $\begin{array}{l}\text { Vieira, } \\
\text { Garcia, } \\
\text { Maciel, } \\
2020\end{array}$ & $\begin{array}{l}\text { Study of the } \\
\text { stressful effects } \\
\text { of the } \\
\text { pandemic on } \\
\text { the } \\
\text { phenomenon of } \\
\text { domestic } \\
\text { violence }\end{array}$ & $\begin{array}{c}\text { Systematic } \\
\text { review }\end{array}$ & $\begin{array}{c}11 \\
\text { scientific } \\
\text { studies and } \\
\text { report }\end{array}$ & $\begin{array}{l}\text { Relations between } \\
\text { social isolation } \\
\text { during the pandemic } \\
\text { and the increase in } \\
\text { violence against } \\
\text { women }\end{array}$ & $\begin{array}{l}\text { The analysis reveals that, at a } \\
\text { global level, the increase in } \\
\text { cases reported to law } \\
\text { enforcement and justice, } \\
\text { corresponds to a reduction in } \\
\text { social assistance and health } \\
\text { services caused by restrictive } \\
\text { measures }\end{array}$ \\
\hline $\begin{array}{l}\text { Humphrey } \\
\text { s, Myint, } \\
\text { Zeanah, } \\
2020\end{array}$ & $\begin{array}{l}\text { Analysis of } \\
\text { domestic } \\
\text { violence in the } \\
\text { context of the } \\
\text { pandemic from } \\
\text { Covid-19 }\end{array}$ & $\begin{array}{c}\text { Systematic } \\
\text { review }\end{array}$ & $\begin{array}{l}7 \text { scientific } \\
\text { studies and } \\
\text { report }\end{array}$ & $\begin{array}{l}\text { Relations between } \\
\text { social isolation } \\
\text { during the pandemic } \\
\text { and the increase in } \\
\text { domestic violence }\end{array}$ & $\begin{array}{l}\text { According to researchers, the } \\
\text { pandemic has triggered violent } \\
\text { dynamics within families due } \\
\text { to the negative emotions } \\
\text { generated by the pandemic }\end{array}$ \\
\hline $\begin{array}{l}\text { Bouillon- } \\
\text { Minois., } \\
\text { Clincham } \\
\text { ps, } \\
\text { Dutheil, } \\
2020\end{array}$ & $\begin{array}{l}\text { Analysis of } \\
\text { domestic } \\
\text { violence } \\
\text { following the } \\
\text { pandemic from } \\
\text { Covid-19 }\end{array}$ & Editorial & $\begin{array}{c}10 \\
\text { scientific } \\
\text { studies and } \\
\text { report }\end{array}$ & $\begin{array}{l}\text { Relations between } \\
\text { social isolation } \\
\text { during the pandemic } \\
\text { and the increase in } \\
\text { domestic violence }\end{array}$ & $\begin{array}{l}\text { According to the analysis, the } \\
\text { risk of aggression and violence } \\
\text { triggered by the stress induced } \\
\text { by the pandemic is greater } \\
\text { than the pandemic itself }\end{array}$ \\
\hline $\begin{array}{l}\text { Conejeroe } \\
\text { t al., } 2020\end{array}$ & $\begin{array}{l}\text { Assessment of } \\
\text { the impact of } \\
\text { the pandemic } \\
\text { on suicide risks }\end{array}$ & $\begin{array}{l}\text { Narrative } \\
\text { review }\end{array}$ & $\begin{array}{c}90 \\
\text { scientific } \\
\text { studies }\end{array}$ & $\begin{array}{l}\text { Relationship } \\
\text { between psycho- } \\
\text { social stress } \\
\text { determined by } \\
\text { Covid-19 and } \\
\text { suicidal behavior }\end{array}$ & $\begin{array}{l}\text { The study emphasizes that the } \\
\text { pandemic from Covid-19, real } \\
\text { pandemic of the solitude, has } \\
\text { determined an increase of the } \\
\text { suicidal behaviors in the world }\end{array}$ \\
\hline $\begin{array}{l}\text { Killgoreet } \\
\text { al., } 2020\end{array}$ & $\begin{array}{l}\text { Assessment of } \\
\text { the impact of } \\
\text { the pandemic }\end{array}$ & Survey & $\begin{array}{c}1013 \\
\text { participants }\end{array}$ & $\begin{array}{l}\text { Relationship } \\
\text { between fear and } \\
\text { insomnia and the }\end{array}$ & $\begin{array}{l}\text { Researchers conclude that the } \\
\text { fear generated by the } \\
\text { pandemic reveals a greater }\end{array}$ \\
\hline
\end{tabular}


on suicidal

ideation manifestation of

suicidal behavior empirical association than

insomnia, with the

manifestation of suicidal behavior

\subsection{Discussion}

The review of the selected studies and scientific evidence reveals an empirical frame of reference which allows a broad definition of the phenomenon. Indeed, although the impact, implications and consequences of this epidemic on global mental health have not yet been fully investigated, review of scientific literature reveals that there is a correlation between $(p>\alpha)$ the spread of the disease and the increase in the prevalence of psycho-emotional and social distress, from fear to distress to anger in the general population, with values ranging from $57 \%$ to $73 \%$ of cases observed. Specifically, these are emotional states linked to fear of contagion and the risk of impoverishment (Brooks et al., 2020). Among the elements of greatest interest it is frequently revealed that anger, fear and psychosocial discomfort have roots prior to the pandemic which, in this sense, seems to have acted as a slatentizing factor or as an amplifier of a condition of pre-existing fragility (Shanahan et al., 2020).

As anticipated, the review revealed a focus research report on domestic violence, against women and children, and suicides. Again, the evidence reveals a correlation $(p>\alpha)$ between the phenomena, most likely due to restrictive measures to limit the contagion. Indeed, the progressive spread of the pandemic has been accompanied by a worrying increase in domestic violence in the world. Despite the meagre data available, the reconstructed empirical picture appears worrying, revealing almost three times as many cases globally as in the previous year (GrahamHarrison et al., 2020; Gupta, Stahl, 2020; Allen-Ebrahimian, 2020). Only in Italy, according to data from the National Institute of Statistics (ISTAT) the victims who asked for help from the beginning of the year to 31 July more than doubled compared to the same period of 2019 , by recording a $+59 \%$ and with a preponderance of violence that is consumed in $93,4 \%$ of cases within the home (Istat, 2020).

A further indication linked to restrictive measures to contain contagion stems from worries of the various international organisations - from World Health Organization (WHO) to associations of psychology and psychiatry - for the spread of suicidal behaviors related to a real "pandemic" of loneliness, fear, anguish. To this condition must be added the effects produced by the processes of social labeling and discrimination through the so-called "stigma of the plague-spreader" that affects subjects and communities at risk of contagion, as well as positive subjects and their families also in relation to the countries of origin; in particular, these are dynamics observed in almost $50 \%$ of cases, of which are victims especially those of the age group 55-85 years. These phenomena associated with the Covid-19 pandemic, in addition to generating a strong sensitivity to dangers and social threats, are positively associated $(\mathrm{p}>\alpha)$ with the risk of suicide (Conejeroet al., 2020; Killgoreet al., 2020). In Italy, according to data from the Covid Suicide Observatory, of the Brain Research Foundation, from the beginning of March to the date of 31 July 2020, 62 suicides and 37 attempted suicides related to the pandemic were recorded by Covid-19; 44 other suicides and 25 other suicides from unknown causes ${ }^{3}$, confirming a phenomenon related to the psycho-social discomfort induced by the pandemic and its consequences.

\section{Conclusions}

On 30 January 2020, the WHO declared the new Coronavirus epidemic as a public health emergency of international interest. It is a decision linked to the global dynamics of a disease whose epidemiological characteristics, still surrounded by an aura of unpredictability and unknowability, define a picture of risks and dangers to the physical health and psycho-social balance of people. Specifically, these are dynamics and circumstances which, although they have already manifested themselves in the past, in this case they seem to reveal a severity such as to disorientate the institutions of the whole world and destabilize the systemic balances of the different areas of life in a lethal way, with emotional and psycho-social consequences so worrying as to require targeted interventions for the different categories for the different categories of people affected (Taleviet al., 2020).

In this regard, the European College of Neuropsychopharmacology (ECNP) stressed the need to reconsider the concept of "resilience", judged as fundamental to address the destabilization produced by the pandemic and manage individual and systemic balances. In view of the organisational and financial efforts that the pandemic has imposed on governments around the world, the international financial organisations are predicting an unprecedented economic crisis that threatens to undermine the future of entire societies, as well as of individuals. The Covid-19 upset the consistency, quality and rhythms of our daily life. Hence the need for scientific communities and life sciences to establish a research programme for the development of evidence-based resilience recommendations and policies for both the general population and the different cohorts of people, on the basis of different sociographics variables.

\footnotetext{
${ }^{3}$ https://www.fondazionebrf.org/osservatorio-suicidi-covid-19/
} 
In the specific case, the concept of resilience refers to policies that states, both individually and through collaboration, should implement: from the strengthening of welfare to the reduction of inequalities, from maximum accessibility to health to increased funding for research and education, from modernisation of infrastructure to promotion of employment opportunities, to which should be added a rapid and reliable institutional communication for the full understanding of potential risks and strategies to address them (Vinkerset al., 2020).

Moreover, in the face of the anthropological explosion of fear, accompanied by widespread anger, collective psychological hallmark of recent months, of which spoke the Italian sociologist Giuseppe De Rita (De Rita, 2020), there seem to emerge timidly dynamics of social solidarity that see communities gather around an idea of social belonging and collaboration. And, above all, there seems to emerge a new demand for a welfare state, which years of uncontrolled neoliberalism and celebration of the market have irretrievably compromised, and new paradigms of assistance and social protection capable of leaving no one behind.

\section{References}

Allen-Ebrahimian B. (2020). China's domestic violence epidemic. Axios. Mar 7. https://www.axios.com/chinadomestic-violence-coronavirus-quarantine-7b00c3ba-35bc-4d16-afdd-b76ecfb28882.html

Bezerra C. V. A., da Silva M. C. E., Soares F. R. G., da Silva J. A. M. (2020). Factors associated with people's behavior in social isolation during the COVID-19 pandemic. CienSaudeColet. Jun; 25 (suppl 1): 24112421. DOI: $10.1590 / 1413-81232020256.1 .10792020$

Bordoni C. (2020). Nella post-società la nostra vita non è più liquida. Corriere della Sera. La lettura. 2 agosto.

Bouillon-Minois J. B., Clinchamps M., Dutheil F. (2020). Coronavirus and quarantine: catalysts of domestic violence. Violence Against Women. Jul 6; DOI: 10.1177/1077801220935194

Brooks S. K., Webster R. K., Smith L. E., Woodland L., Wessely S., Greenberg N., Rubin G. J. (2020). The psychological impact of quarantine and how to reduce it: rapid review of the evidence. Lancet. Mar 14; 395(10227): 912-920. DOI: 10.1016/S0140-6736(20)30460-8

Cerbara L., Ciancimino G., Crescimbene M., La Longa F., Parsi M. R., Tintori A, Palomba R. (2020). A nationwide survey on emotional and psychological impacts of COVID-19 social distancing. Eur Rev Med Pharmacol Sci. Jun 24 (12): 7155-7163. DOI: 10.26355/eurrev_202006_21711.

Conejero I., Berrouiguet S., Ducasse D., Leboyer M., Jardon V., Olié E., Courtet P. (2020). Suicidal behavior in light of COVID-19 outbreak: Clinical challenges and treatment perspectives. Encephale. 2020; Jun; 46 (3S): S66-S72. Published online. DOI: 10.1016/j.encep.2020.05.001

Corbin J., Strauss A. (1990). Grounded theory research: procedures, canons, and evaluative criteria. Qualitative Sociology, Mar; 13 (1): 3-21.

De Rita G. (2020). Dopo la paura, ecco la rabbia che causa le solite divisioni. Corriere della Sera. 23 maggio

Del Carmen Pérez-Fuentes M., Del Mar MoleroJurado M., MartosMartínez Á., JesúsGázquez Linares J. (2020). Threat of COVID-19 and emotional state during quarantine: Positive and negative affect as mediators in a cross-sectional study of the Spanish population. PLoSOne. Jun 25;15(6):e0235305. DOI: 10.1371/journal.pone.0235305

Giarelli G., Venneri E. (2009). Sociologia della salute e della medicina. Manuale per le professioni mediche, sanitarie e sociali. Milano: FrancoAngeli

Glaser G.B., Strauss L.A. (2012). The discovery of grounded theory: strategies for qualitative research. 7a ristampa. New Brunswich, NJ (USA) and London (UK): Aldine Transaction

Graham-Harrison E., Giuffrida A., Smith H., Ford L. (2020). Lockdowns around the world bring rise in domestic violence. Guardian. Mar 28. https://www.theguardian.com/society/2020/mar/28/lockdowns-world-risedomestic-violence

Gupta A., Stahl A. (2020). For abused women, a pandemic lockdown holds dangers of its own. New York Times. Mar 24. https://www.nytimes.com/2020/03/24/us/coronavirus-lockdown-domestic-violence.html

Hjørland B. (2013). Facet analysis: the logical approach to knowledge organization. Information Processing \& Management. March; 49 (2): 545-557

Humphreys K. L., Myint M. T., Zeanah C. H. (2020). Increased Risk for Family Violence During the COVID-19 Pandemic. Pediatrics. Jul; 146 (1): e20200982. DOI: 10.1542/peds.2020-0982

Istat (2020). L'allerta internazionale e le evidenze nazionali attraverso i dati del 1522 e delle Forze di Polizia. La violenza di genere al tempo del coronavirus: Marzo - Maggio 2020. In https://www.istat.it/it/violenzasulle-donne/speciale-covid-19

Killgore W. D. S., Cloonan S. A., Taylor E. C., Fernandez F., Grandner M. A., Dailey N. S. (2020). Suicidal ideation during the COVID-19 pandemic: The role of insomnia. Psychiatry Res. May 27; 290:113134. DOI:10.1016/j.psychres.2020.113134

Lwin M. O, Lu J., Sheldenkar A., Schulz P. J., Shin W., Gupta R., Yang Y. (2020). Global Sentiments Surrounding the COVID-19 Pandemic on Twitter: Analysis of Twitter Trends. JMIR Public Health Surveill. May 22; 6 (2): e19447. DOI: 10.2196/19447 
Mahase E. (2020). Covid-19: EU states report 60\% rise in emergency calls about domestic violence. BMJ. May 11; 369: m1872. DOI: $10.1136 / \mathrm{bmj} . \mathrm{m} 1872$

Marques E. S., Moraes C. L., Hasselmann M. H., Deslandes S. F., Reichenheim M. E. (2020). Violence against women, children, and adolescents during the COVID-19 pandemic: overview, contributing factors, and mitigating measures. CadSaudePublica. April 30; 36 (4): e00074420. DOI: 10.1590/0102-311X00074420

Moreira D. N., da Costa M. P. (2020). The impact of the Covid-19 pandemic in the precipitation of intimate partner violence. International Journal of Law and Psychiatry. Jul-Aug; 71. Published online. doi.org/10.1016/j.ijlp.2020.101606

Roesch E., Amin A., Gupta J., García-Moreno C. (2020). Violence against women during covid-19 pandemic restrictions. BMJ. May 7. 369: m1712. DOI: 10.1136/bmj.m1712

Ruggeri F. a cura di (2010). Quale salute per chi. Sulla dimensione sociale della salute. Milano: FrancoAngeli.

Sala V., Moja L., Moschetti I., Bidoli S., Pistotti V., Liberati A. (2006). Revisioni sistematiche. Centro Cochrane Italiano. In www.cochrane.it

Shanahan L., Steinhoff A., Bechtiger L., Murray A. L., Nivette A., Hepp U., Ribeaud D., Eisner M. (2020). Emotional distress in young adults during the COVID-19 pandemic: evidence of risk and resilience from a longitudinal cohort study. Psychol Med. Jun 23; 1-10. DOI: 10.1017/S003329172000241X

Talevi D., Socci V., Carai M., Carnaghi G., Faleri S., Trebbi E., di Bernardo A., Capelli F., Pacitti F. (2020). Mental health outcomes of the CoViD-19 pandemic. RivPsichiatr. May-Jun; 55 (3): 137-144. DOI: $10.1708 / 3382.33569$

Torales J., O'Higgins M., Castaldelli-Maia J. M., Ventriglio A. (2020). The outbreak of COVID-19 coronavirus and its impact on global mental health. Int $\mathrm{J}$ Soc Psychiatry. Jun; 66 (4): 317-320. DOI: $10.1177 / 0020764020915212$

Trnka R., Lorencova R. (2020). Fear, anger, and media-induced trauma during the outbreak of COVID-19 in the Czech Republic. Psychol Trauma. Jul; 12 (5): 546-549. DOI: 10.1037/tra0000675.

Vinkers C. H., van Amelsvoort T., isson J. I., Branchi I., Cryan J. F., Domschke K., Howes O. D., Manchia M., Pinto L., de Quervain D., Schmidt M. V., van der Wee N. J. A. (2020). Stress resilience during the coronavirus pandemic. EurNeuropsychopharmacol. Jun; 35: 12-16. DOI: 10.1016/j.euroneuro.2020.05.003

Vora M., Malathesh B. C., Das S., Chatterjee S. S. (2020). COVID-19 and domestic violence against women. Asian J Psychiatr. Jun 15; 53: 102227. DOI: 10.1016/j.ajp.2020.102227 